The Version of Record of this manuscript has been published and is available in History of European Ideas (2019) https://www.tandfonline.com/DOI:

$10.1080 / 01916599.2019 .1664803$

\title{
Placeless People. Writing, Rights and Refugees,
}

by Lyndsey Stonebridge. Oxford: Oxford University Press, 2018

\section{ANDRE SANTOS CAMPOS}

Lyndsey Stonebridge's Placeless People. Writing, Rights and Refugees expresses the uncommon (yet, not unfruitful) ambition of addressing the political problem of forced massed displacement of people from the viewpoint of cultural (mostly, literary) history. This makes her book difficult to place within the more traditional disciplinary categories since it works at the intersection of different areas of research. It is, firstly, a collection of texts that could easily fall under the purview of 'literary studies' about a common theme. Secondly, it is a book of 'intellectual history' on some cultural negative reactions to mid- $20^{\text {th }}$-century trends of nationalism and humanitarianism. Thirdly, it is an open critique to how leniently the problem of statelessness has been tackled in 'political theory' since Hannah Arendt first formulated it. And fourthly, it contains a reflection on the 'philosophical' implications of what Stonebridge calls 'the placeless condition'.

This admixture of elements, which could easily have become a complex melting pot or an intricate web of nonrelated perspectives, is the book's richest quality. Stonebridge is able to strike a balance between her overlapping intentions and the text never seems overambitious or wandering from thought to thought. Her writing contains elegance and even some measure of poignancy. This helps lead the reader, by the hand, towards her goal, never actually losing sight of the common ground supporting the different chapters.

The underlying thesis of the book can be summarized easily. The forced mass displacement of people that gives rise to such political, moral and legal categories as 'refugees' and 'stateless persons' is a modern phenomenon caused both by the crisis of the traditional nation-state paradigm of sovereignty and citizenship and by the inconsequent naiveté of post-war humanitarianism. There is no such thing as a 'refugee problem' except as a side effect of the inadequacy of nationalism and humanitarianism for securing the implementation of the right to have rights assigned to each person in reason of her belonging to a place. The placeless condition in which millions of people are compelled into 'thinking and being between nation-states' is considered by 
Stonebridge the realm of rightlessness. The book's turn to literary history intends to appeal to novel and creative solutions to bring those that fall outside the margins of citizenship into the human condition of being placed, that is, of being a concrete rightbearer. Authors such as Arendt, Kafka, Orwell, Weil, Beckett and Auden are brought to the fore not only because they all allowed the experiences of forced displacement in their times to affect their reflections on refugees and stateless persons, but also because they are representative of how literature can offer an innovative model whereby to conceive of forms of political inclusion without depending on state sovereignty or mere humanitarian relief to resolve the (inhuman) condition of people cast out. Following Edward Said's insights, Stonebridge suggests that we should deepen our knowledge of authors that refused to render dignity to the displaced, as opposed to the wave of humanitarian Weltileratur that tried to 'humanize the inhuman'.

The line connecting these dots is, as expected, Hannah Arendt, whose reflections on migration constitute the central axis around which all the chapters in the book turn. Arendt is mentioned in every chapter and often the choice of the author with which Stonebridge is engaging seems to be justified merely by how he or she relates to Arendt or Arendt's work. Indirectly, this book could also fall under the ever-expanding category of 'Arendt Studies'.

Placeless People is divided into three parts. The first focuses on the notion of statelessness and comprises two chapters on how this concept emerges from Arendt's acquaintance with certain literary texts. Chapter 1 introduces the idea that Arendt's reading of Kafka influenced her writings on refugees and stateless persons - especially her now-famous essay 'We Refugees' and what would later become the often-quoted chapter 'The Decline of the Nation-State and the End of the Rights of Man' in The Origins of Totalitarianism. The character K. in Kafka's The Castle is regarded by Arendt as the fictional representative of a condition of strangeness that prefigures the empty political existence of post-war refugees. His position as an outsider is, however, countenanced by an attitude that permanently challenges the instituted authorities, as well as the claims of universal rights and of the ensuing humanitarianism. He is the pariah who is turned by Arendt's reading into a historically and politically situated advocate for rights. According to Stonebridge, this interpretation of The Castle offers us a glimpse of two main theses that Arendt will develop in The Human Condition: that the new is central to political life; and that new forms of political community must be devised if rights are to function beyond the confines of traditional nation-states.

Chapter 2 develops the intuition that Arendt's thinking about politics depends to a certain extent upon her relation with poetic language and literary history. The symptoms of statelessness cannot be cured by the same tools that supposedly created them in the first place, so the imagination and the creativity which abound in the fictional world must be brought to the historical world. Stonebridge reaches this conclusion by focusing on Arendt's acquaintance with Rahel Varnhagen's life and works and on Arendt's reading of Bertold Brecht's poems on exile. The main point is that Varnhagen illustrates the new pariah which is still extant in old forms of 
Weltliteratur, and that a novel form of human community found between Brecht's lines can endure beyond the nation-state.

The second part of the book contains three chapters, each on a specific writer's version of placeless people. Chapter 3 depicts George Orwell's conflicting relation with Jewishness and how exile is ultimately portrayed in Nineteen Eighty-Four as an example of the crisis of mid-century conceptions of national sovereignty. Chapter 4 highlights Simone Weil's struggle against uprootedness and deracination as violent forms of emptying someone of perspective. Like Arendt, her rejection of the human rights doctrine of humanitarianism followed from the fact that it depended too much on a conception of personalism that contributed to uprooting people rather than help them belong to a specific community. Stonebridge closes the chapter by identifying a curious case of Weil's uprooted in Roberto Rossellini's film Stromboli. In chapter 5, the placeless people are 'the expelled', especially as they are framed by Samuel Beckett's short stories collectively known as the Nouvelles, written between 1945-6. Stonebridge draws a successful comparison between Arendt's interpretation of Kafka's K. and the vicissitudes of legal and administrative absurdism suffered by Beckett's characters. Her point is that Beckett's characters 'are the new clowns of the post-war age of compromised humanitarianism, ironists of their own suffering, chroniclers of the gap that opened up between the rightless and the rest of the world' (136).

The third and final part of the book gathers two chapters. Chapter 6 focuses on Dorothy Thompson's depiction of Palestinian refugees in her 1950 documentary Sands of Sorrow. Stonebridge maintains that Thompson's 1950's position concerning refugees shows that they are not mere consequences of war but rather the products of the failure of nationalism 'to realize a global sovereignty based on humanist principles' (160). And chapter 7 relates statelessness with the condition of 'being on the borderline', more specifically in the poetry of W.H. Auden and of Yousif M. Qasmiyeh.

The book ends somewhat unexpectedly, without a conclusion or any other kind of postscript. The reader is not necessarily left wondering what more is there to say since Stonebridge summarizes her underlying intentions at the beginning of the last chapter. The texts she has been discussing, she claims, 'are important for two reasons: first, as chronicles and responses to refugee history, and, second, because their authors, in different ways, write about displacement to propose and imagine alternatives for citizenship and sovereignty at a moment when the question of what it meant to belong to a nation was at its most vexed' (168). However, these two reasons, which are perfectly adequate to justify reading any given chapter picked up randomly, seem highly unsatisfactory to someone who has accompanied the author's trend of thought for so many pages. In fact, they fail to answer many questions that the introduction purportedly left open.

The first question concerns the criteria for the selection. Why these authors in particular, and not others? Is there something specific about these authors that distinguishes them from other $20^{\text {th }}$-century writers who developed important insights on 
uprootedness and refugees, some of them even somehow connected with Arendt, such as Walter Benjamin, Albert Camus, Isaiah Berlin? The selection is justified by a common critique of placelessness attributed to the crisis of nationalism and humanitarianism, but Stonebridge never clarifies how seriously one should take this criterion insofar as it excludes other authors typically associated with the literature on forced migration. One cannot, therefore, accuse the reader of suspecting that there is no relevant reason for this particular cast of characters beyond the author's taste.

The second question concerns the genres of the cultural products tackled by Stonebridge. Why these genres in particular (for instance, Arendt's essays, Orwell's novel, Beckett's short stories, Auden's poetry) rather than others? The question is particularly relevant in the light of Stonebridge's occasional attention to films, especially in chapter 6 . What is it about these specific pieces of writing that justify relating them to cinema rather than other art forms? The book seems to begin from the premise that literary studies have something important to say to problems inherent in contemporary political theory, so the reader is left guessing why chapter 6 was included in the book at all.

The third question concerns the organization of the book. Why the division in three parts? Arendt plays a central role in the first two chapters, which is reason enough to connect them into one single section. But what distinguishes the essays contained in parts 2 and 3 that justifies their division? For instance, the chapter on Auden's view of the borderline could just as easily be considered a different version of placeless persons and therefore be included in part 2. In addition, why does Orwell precede Weil and Beckett? Why is the chapter on Beckett the final chapter of part 2? Stonebridge never actually tells us, so the reader cannot once more be accused of suspecting the presence of randomness.

But the main question left open is theoretical. The claim that the authors discussed in this book 'write about displacement to propose and imagine alternatives for citizenship and sovereignty' (168) sounds like an overstatement, to say the least. One can be sympathetic to the view that they suggest the need to develop alternatives for the political inclusion of refugees and stateless persons. But that is still far from maintaining that they propose alternatives for citizenship and sovereignty. When she makes this claim, Stonebridge is obviously thinking about Arendt, about whom the sentence makes perfect sense. But such works as Nineteen Eighty-Four, the Nouvelles, Weil's essay on the Iliad, and Sands of Sorrow, can hardly be interpreted as containing such proposals, much less as providing (even implicitly) an alternative answer to contemporary problems of mass displacement.

If this reasoning is correct, then Stonebridge's book, even though based on an appealing thesis and written in a very enjoyable style, does not seem to have anything new to offer to the debate about forced mass migrations besides its innovative methodological approach. The very title of the book seems somewhat uncertain in the light of the multitude of concepts used to express the same phenomenon. The book is 
supposed to be about placeless people, but its main thesis tells us that it is about statelessness in the broad sense introduced by Arendt, whereas the authors analysed throughout the book are said to invoke uprootedness, refugees, exile, borderliners and strangeness. This conceptual indeterminacy, however, is quite troublesome. Indeed, Arendt used the word 'stateless' to describe 'refugees, political exiles, temporarily denaturalized citizens', those 'who had been stripped or their citizenship altogether' (14). But Arendt wrote at a time in which the international human rights practice was still taking its first steps and there were no alternative legal frameworks to the nationstate and international public law. The present state of 'post-national sovereignty' or even 'post-sovereign sovereignty' that gave rise to what is usually called 'global legal pluralism' and to several instances of soft law, however, entails applying terminology in a much more demanding way. For instance, one can be a political exile without being a refugee and one can be a citizen while being a refugee, such as occurs in cases of forced migration due to poverty and climate change, two phenomena not mentioned once in Stonebridge's work. It is even conceivable that one can be a refugee without falling through the cracks of the nation-state, in which case one could be stateless without necessarily being placeless. The moment a nation-state recognizes someone as a refugee and implements legal instruments of accommodation, she is being recognized as a rightbearer, as a person with a right to a place, even if temporary, even while remaining stateless. The very act of recognition embodies that particular person in a specific legal context within a territory, despite falling short of being actual political inclusion.

Ultimately, there are differences between statelessness and placelessness that cannot be brushed aside so abruptly. Statelessness is mostly a normative concept, whereas placelessness can be much more - it refers to a relation between identity and territory, but also between body and space, life and property, particularity and community. The challenge of statelessness to refugees is whether they have a state or not; and, if so, which state; if not, how to integrate them into a political community. The challenge of placelessness, however, is not so much whether refugees have a right to a place, but rather to which place they have a right to lay roots. Stonebridge seems to refer often to stateless persons in the sense of placeless persons, and vice versa. This confuses the reader and, if she does it intentionally, she should at least provide explicit warnings and present her reasons.

Stonebridge does make an important argument amidst this context, though. The problem with refugees follows from the challenges to traditional conceptions of sovereignty and citizenship used to explain novel phenomena. And there is much that literary studies can offer to political theory in this respect. The means of escape from traditional conceptions in the history of political thought can be glimpsed in works such as Stonebridge's. Perhaps there is a whole area of research still to be explored, of which her book can be considered pioneer. It remains to each reader to discover for herself. 